\title{
Kick a ball with a bubble
}

Gabriel Guenoun², Will Growe', Stéphane Poulain ${ }^{3}$, and Sunghwan (Sunny) Jung1

${ }^{1}$ Biomedical Engineering and Mechanics, Virginia Tech, Blacksburg, VA

2Physics Department, ENS Gachan, France

3DAEP, Université de Toulouse, ISAE-Supaero, Toulouse, France
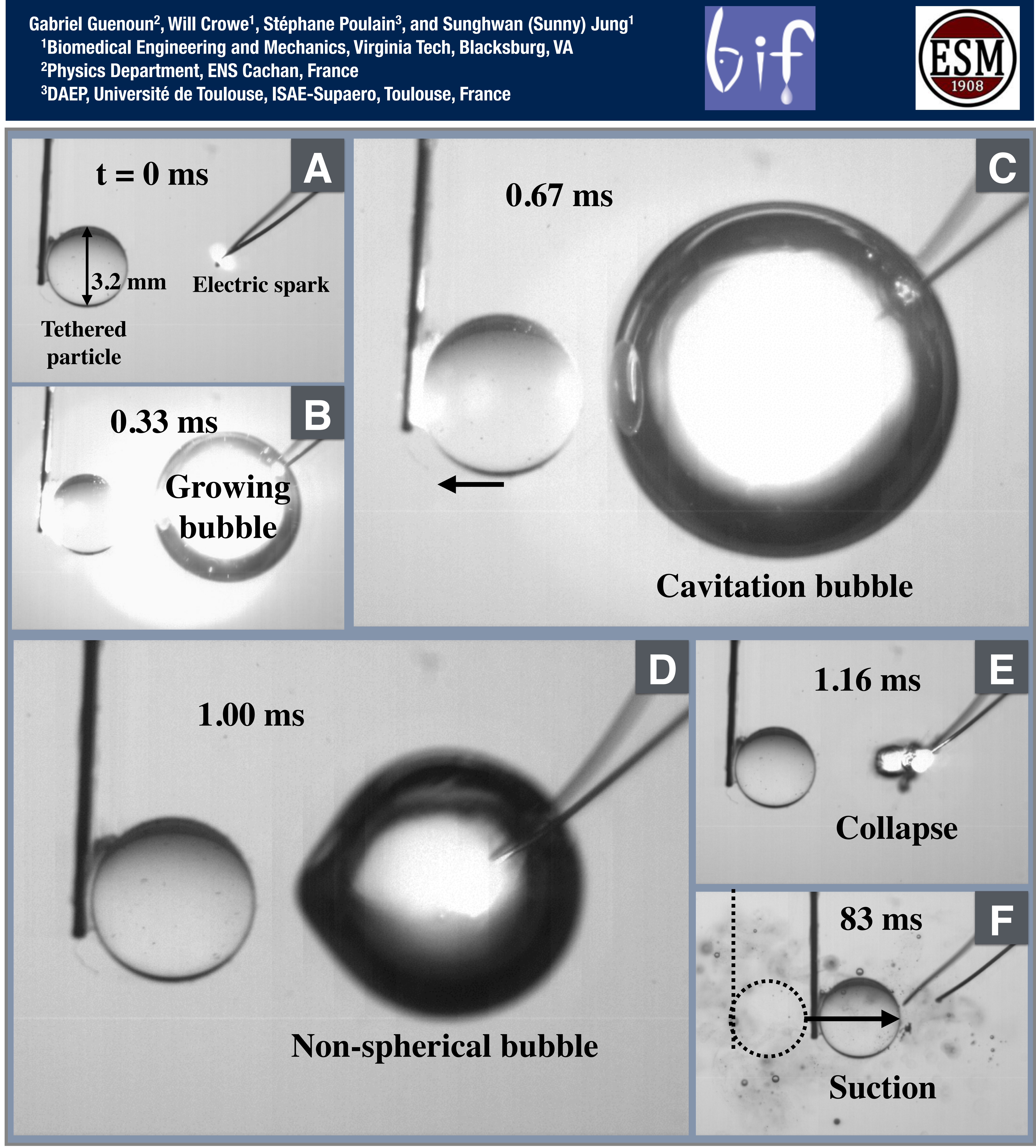